\title{
Determinants of Military Turnover of Technical Air-force Specialists: An Empirical Case Analysis
}

\author{
Chengedzai Mafini \\ Logistics Department, Faculty of Management Sciences, Vaal University of Technology \\ E-mail: chengedzai@hotmail.com \\ Job Dubihlela \\ Faculty of Management Sciences, Vaal University of Technology. South Africa \\ E-mail: job@vut.ac.za
}

\section{Doi:10.5901/mjss.2013.v4n3p523}

\section{Abstract}

Military turnover involving air force staff is a unique and rare phenomenon. Eyebrows were therefore raised when it was observed that there were hundreds of aircraft technicians who were ex-members of a particular government air force organisation, and were now concentrated in one geographic location, which was distant to their homes. This incident had to be empirically investigated, and the causes for the mass exodus explained. We explored antecedent factors contributing to the mass exodus of aircraft technicians from an air force in Southern Africa. Turnover occurring in military organisations is infrequent and does not often attain disturbing levels. Nevertheless, there was an alarming mass departure of aircraft technicians from a particular air force organisation; a development which merited an empirical investigation. It is important to understand the drivers of turnover in military organisations, as this facilitates the more effective planning of various human resource practices within that organisation. A cross-sectional survey design was applied on a convenient sample of aircraft technicians ( $n=231)$. Exploratory factor analysis (EFA) was applied to identify factors contributing to the Regression analysis was used to test relationships between the extracted factor. The mean-score ranking approach was used to examine the importance of the factors relative to each other. Six factors that accounted for $64.9 \%$ of the variance were extracted, namely job satisfaction, management style, job content, employment equity, individual cognition and personality, economic and employment opportunities. Inter-factor relationships and predictor variables were identified. Among these factors, job satisfaction was found to be the most important factor and internal equity was the least important factor that contributed to the attrition of aircraft technicians. To retain their specialist staff, managers in military organisations must pay special attention to the factors identified in this study. Optimisation of these factors is important in reducing the intention to quit among specialists in military organisations. The findings of the study are useful in the attraction, reward and remuneration, selection, development, placement and retention of critical employees in military organisations. The results are important for managers intending to retain scarce skills; they provide valuable pointers for designing effective retention strategies.

Keywords: Aircraft technicians, staff turnover, military organisations, Air-force, Southern Africa

\section{Introduction}

In most contemporary organisations, the retention of employees who have specialised skills has emerged as a strategic priority in recent times (Van Dyk \& Coetzee, 2012). In general, turnover is renowned for its disruptive effects on organisational effectiveness in all industries (Bosman, Buitendach \& Rothmann, 2005). Although it is a rather infrequent phenomenon in military organisations, technical personnel also voluntarily withdraw their services from military organisations for various reasons (Krueger, 2001). The replacement of specialised technical manpower remains an intimidating challenge, a factor which has compelled many countries are prioritising the retention of qualified military personnel, (Knapp, 1993).

The turnover of aircraft technicians from military organisations triggers consequences that are more damaging and far-reaching within military organisations than in other industry sectors (Lane, 2006). Military staff turnover reduces the organisation's manpower levels, a matter which may compromise operational effectiveness and overall national security (Hosek \& Totten, 2002). Moreover, turnover generally increases the workload and demands on the remaining personnel, resulting in frustrations, burnout, overwork possible greater attrition of personnel (Stroth, 2010). Military organisations are not immune to these general effects of turnover. 
The exodus of aircraft technicians from military organisations could be attributed to several factors and various employee challenges such as a poor person-organisation fit, a demanding workload as well as prolonged physical and emotional stress, which are common conditions during periods of war (Murnieks, Allen \& Ferrante, 2011). These factors have negative effects on employee performance (van-Schalkwyk, Du Toit, Bothma \& Rothmann, 2010) and cause 'burnout', a syndrome of emotional exhaustion, depersonalisation and reduced personal accomplishments (Schaufeli \& Van Dierendonck, 1993). Krueger (2001) defines emotional exhaustion as feelings of being overextended and depleted of one's emotional resources. Depersonalisation refers to a negative, callous or excessively detached response on workmanship to other people (Knapp, 1993). This leads the employees to feel dehumanised and to develop a negative evaluation of self in a work environment. Feelings of reduced personal accomplishments pertain to an unfortunate scenario where employees feel that their employment is worthless (Coetzee, Schreuder \& Tladinyane, 2007). As such, in order to address the problem of turnover, factors that trigger the phenomenon must be controlled in the first instance.

To avert such possible consequences, it is important to identify organisational, work and individual-related factors contributing to dysfunctional military turnover. As noted earlier, turnover which is voluntary and dysfunctional is seriously costly to organisations. Therefore, understanding the process within which turnover unfolds is vital for the organisation as it creates space for management to implement appropriate corrective actions and initiate proactive strategies that prevent similar challenges from occurring in the future. It also enhances the proper planning of recruitment, training, promotion and other career management activities for employees (Sumer, 2005).

\section{Literature review}

\subsection{Staff Turnover}

Staff turnover may be perceived as the rate at which an organisation gains and loses employees (Stroth, 2010). It is determined in terms of how long employees stay in their employment positions. Factors that influence the departure or facilitate the retention of employees and their decisions to leave are based on a comprehensive body of the literature on staff turnover, rooted in authoritative organisational science research (Griffeth \& Hom, 2001). The groundbreaking theories on turnover were relatively simple, relating turnover directly to job attitudes such as satisfaction and commitment (Clark \& Harcourt, 2004). Among the latter models, decision-making processes involved in withdrawal were emphasised proposing various intermediate linkages between turnover and its causes (Holden, 2010). The original formulation was later modified and revised to contribute significantly to the accumulation of the turnover literature. The aforesaid studies posit that staff turnover is detrimental in organisations where the productive capacity is concentrated in the knowledge, skills and abilities of employees (Bureau of Labor Statistics, 2005). Similar sentiments are echoed by a number of scholars (von Greiff, 2009; Schwerdt et al., 2010) who also sustain that in organisations where the abilities of management are the prime success driver, attrition of these critical employees is likely to be dysfunctional. This suggests that it may be important to diversify the sources of productivity in order to minimise losses in the event of an increase in the turnover of skilled employees.

For organisations that are highly dependent on specialised technical personnel, a sustained high staff turnover represents a depletion of operational capacity, significant reduction in organisational effectiveness and a threat to the technical organisational core (Mouritsen, Bukh \& Marr, 2004). In any organisation, excessive turnover ultimately leads to reduced service capacity, higher costs and an increased possibility for harmful decisions (Lytell \& Drasgow, 2009). The importance of military organisations' stock of technical skills is even greater where "knowledge-intensive" air-force services are the final product. Both the productive process and the sustenance of the organisation are embodied in the personnel (aircraft technicians).

Turnover theory continues to evolve in specialised technical fields with on-going examination of the turnover process (Campion, 1991), relationships among determinants of turnover (Tang, Kim \& Tang, 2005), turnover intentions (Dunn \& Morrow, 2002) and the impact of turnover behaviour (Knapp, 1993; Glaser, 1996) on the individuals, the organisation and the systems. All organisations naturally experience turnover to a certain extent (Meyer \& Allen, 1997). The knowledge of the underlying causes for staff turnover is necessary to yield information on retention strategies as well as evidence on why personnel leave organisations, or their profession altogether. Skilled personnel are important for organisations if they are to attract, motivate and retain key talent (Morrow, 2011). Organisational employee-centred human resource practices such as work-life balance, compensation, supervisor support, rewards and recognition, training and development, job characteristics, and opportunities to develop careers influence the commitment of employees (Clark \& Harcourt, 2004; Joāo, 2010). Therefore, such factors always occupy the core of most research on staff turnover. 


\subsection{Military Turnover}

Military turnover derives its meaning from staff turnover; it may be defined as a scenario in which military personnel leave or withdraw their services from military organisations (Hosek \& Totten, 2002). Military turnover may be attributed to a number of reasons. In the first instance, military jobs are naturally physically and psychologically demanding, requiring individuals who possess a high level of physical as well as psychological stamina, thereby compelling those individuals who cannot cope with the these strenuous physical requirements to leave the organisation (Krueger, 2001). Eissenburger et al. (2002) also point out that leadership styles that precipitate sour relations between military leaders and lower ranking members are a major contributor to military turnover. This suggests that a healthy leader-member relationship is a major motivational factor that boosts members' loyalty to the organisation. In agreement, Marcourse et al.(2002) add that labour turnover is high in organisations dominated by inappropriate leadership management practices. Tang et al. (2005) further emphasise that there exists a correlation between levels of motivation and labour turnover.

The findings of a study conducted by Hosek and Totten (2002) reveal that prolonged deployment in a hostile duty has a negative effect on re-enlistment for officers in the military. As military lengthen or become more demanding, involving some degree of risk, they cause stress and disrupt personal life, thereby lowering the morale of members and potentially reducing their possibility of re-enlisting after the expiry of their contracts (Gerritse et al., 2009) An earlier study conducted by Schumm, Bell, and Resnick (2001) also found that family factors are more strongly related to retention of military personnel. In this regard, some military members may leave the organisation in order to spend more time with their families after serving in hostile environments for long periods of time. Furthermore, high organisational turnover may be a direct antecedent of incompatibilities existing between the employee's personality characteristics and the working environment (Bosman et al., 2005). Where a person-environment fit exists, the individual is likely to stay on the job for a long period of time while the opposite is also true.

A meta- analysis conducted by Hom, Caranikas-Walker, Prussia \& Griffeth (1992) concluded that the relationship between job satisfaction and the search for alternative employment was stronger in civilian than in military samples. In agreement, Lytell and Drasgow (2009) maintain that perceived opportunities may not be an important part of military turnover processes, such that some individuals leave the military for reasons that may not necessarily be voluntary (e.g., turnover due to medical problems). Dickter, Roznowski and Harrison (1996) underscore that turnover may be perceived to be merely a final act following some series of mechanisms that lead to an intent and decision to resign. Steel and Ovalle (1984), Griffeth and Hom (2001) and Lytell and Drasgow (2009) also opine that turnover intentions such as thoughts of quitting and intentions to search for new employment are both immediate precursors of turnover and predictors of turnover.

Findings of studies conducted by Talcott et al. (1999) and Jayawardena (2006) reveal that mental-health-related factors are common predictors of turnover for the United States Air Force as well as among gunners in the Sri-Lankan Air Force respectively. Cigrang, Todd, and Carbone (2000) further reiterate that mental-health-related problems play a critical role in a significant portion of the turnover/discharge within the first six months of enlistment in the U.S. Armed Forces. In their study on a sample of the Canadian Forces noncommissioned member recruits, Holden and Scholtz (2002) established that depression scores significantly predicted attrition from the military training for both male and female trainees.

Sumer (2005) proposes a model of military turnover in which factors expected to play a critical role in military turnover are grouped under three categories, namely distal factors (i.e., job and organisational characteristics and perceived job alternatives), intermediate/mediating factors (i.e., person-environment - P-E - fit, quality of life - QOL perceptions; and work attitudes, namely job satisfaction, continuance commitment, and affective commitment), and proximal factors (i.e., turnover intentions, unemployment rate, and shocks). Accordingly, job satisfaction among employees is an indicator of organisational effectiveness influenced by organisational and personal factors. Furthermore, identifying critical organisational, job and individual factors in the turnover process has obvious utility implications for military organisations (Asch \& Hosek, 2007). Knapp (1993) suggests that a person's intentions, lower levels of job satisfaction and performance are associated with high probability of military turnover. Smith, Holtom \& Mitchell (2011) also found that job satisfaction and low organisational commitment were strong predictors of turnover among service personnel in the US Air Force. Most employers know that their optimal functioning depends on the level of job satisfaction of employees, hence the emergence of the statement, "Happy employees are productive employees" (Saari \& Judge, 2004). This denotes that for performance to be optimal, employees' full potential is needed at all levels in organisations (Clark \& Harcourt, 2004).

Tang et al. (2005) contend that the more favourable an individual's attitudes toward the organisation, the greater 
the individual's acceptance of the goals of the organisation, as well as their willingness to belong to the organisation. Developing a better perception and organisational commitment has an effect on employees and organisations (Cigrang et al., 1990). The level of employees' organisational commitment will possibly ensure that they are better suited to receive extrinsic and psychological rewards. Organisational commitment is generally assumed to reduce abandonment behaviours, which include tardiness and turnover (Saari \& Judge, 2004).

Military turnover can be negative, extremely dysfunctional, unavoidable and very costly for the defense and security organs of any country (Campion, 1991). The scale of the investments made in the recruitment, selection, classification, and training of military air-personnel is particularly and practically enormous (Gerritse et al., 2009). For instance, the costs of recruiting and training a single aircraft technician can be as much as approximately a quarter of a million United States dollars (USD 252 000) (Holden, 2010). This amount includes the costs incurred from the entire recruitment process for replacements, salaries and obligatory provisions (accommodation, uniforms, transportation, food, etc) throughout the four and half year aircraft engineering training program. These costs can be taken to be unrealistically astronomical especially considering the economic challenges facing developing nations. Therefore, reducing the attrition of qualified aircraft technicians can mitigate these costs.

Other negative effects of turnover include lost opportunities: which are considerations of what the leaver might have achieved for the organisation had he or she stayed, possible subcontracting of work, cost of scrap and poorly done work while replacement staff is learning the job and other unforeseen payments (Birchall \& Morris, 1995). However, in sophisticated situations where the turnover rate is likely to remain constant regardless of efforts to reduce it, a viable strategy may be to combat the negative effects of military turnover without necessarily reducing the rate of military turnover itself (Murnieks, Allen \& Ferrante, 2011). This strategy may particularly be relevant to scenarios in which the attrition has been triggered by factors that are beyond the control of management.

\section{Problem Statement}

The aim of the study was to establish the factors influencing turnover decisions for aircraft technicians at an air force organisation in Southern Africa, investigating respondents' views with respect to individual, psychological, job related as well as environmental factors such as organisational characteristics, working conditions, turnover intentions and the external climate. Representatives of a Dubai based aircraft engineering company known as Gulf Aircraft maintenance Engineering Company (GAMCO) visited South Africa in the year 2012 to recruit aircraft technicians. Interviews, which were to be conducted between the 5th and the 9th of March, were held at a hotel in Sandton, Johannesburg. We took notice of the proceedings and inquired, only to find out that a majority of the interviewees, several hundred in number were aircraft technicians who had resigned en-mass from a government air force organisation in a Southern African country.

There has been an explosion of research interests focusing on staff turnover. Interestingly, much of this research concentrates on the corporate sector as well as on developed economies, whereas there still exists scant evidence of empirical research on military turnover in the context of African military organisations (Lane, 2006). It has also been suggested that research conducted using civilian samples may not be generalised to military samples (Knapp, 1993). It is an important supposition then that the mass attrition of aircraft technicians from a Southern African air force organisation be investigated in order to eliminate the existing knowledge gap within the military set up, especially in the African context.

\section{Research methodology}

\subsection{Research approach}

For the empirical study, we adopted a quantitative approach using across-sectional survey design (Van Dyk \& Coetzee, 2012) to achieve the research objectives. In quantitative research the primary objective is to quantify the collected data and to generalise the results from the sample to the population of interest (Malhotra, 2007). Quantitative research was attractive to this study because it enhances objectivity and is cheap, flexible and less time-consuming to conduct (Cooper \& Schindler, 2011).

\subsection{Measuring instrumentation and data collection}


The questionnaire consisted of a set of 39 items that were adapted from by annotated scales developed by Spector (1997) and Meyer and Allen (1997) which measured levels of job satisfaction and organisational commitment, using varies work related environmental variables. Since the purpose of this study was not to make individual predictions but rather to investigate broad trends and relationships between certain variables, the instrument was considered to be psychometrically acceptable. Previous studies (Coetzee, Schreuder \& Tladidyane, 2007; Döckel, Basson \& Coetzee, 2006; Ferreira, 2009; Van Dyk \& Coetzee, 2012) confirmed the reliability and validity of similar scales in the South African context. The purpose of the study was communicated to all participants prior to the administration of questionnaires. Participation was voluntary.

Permission to collect data was granted by authorities at the hotel in Sandton, Johannesburg, South Africa where interviews were conducted as well as from the representatives from GAMCO. We then administered the questionnaires on site from the 6th of March to the 9th of March 2012 to a conveniently selected sample of 350 individuals. From this number, 237 questionnaires, representing an acceptable response rate of $68 \%$ were returned. Upon screening these questionnaires, six were eliminated because they had errors. This culminated in the 231 usable questionnaires which were employed in the actual data analysis.

The questionnaire elicited data on the working environment (satisfaction with work arrangements, work load, physical accommodations, schedule flexibility, work condition); economic benefits (importance given to salary, pension funds, non-monetary benefits and career prospects); management style (satisfaction with supervisor, cooperation, autonomy, boss-caring); enrichment ( importance given to learning new things, taking courses); feedback ( importance given to getting specific instructions, being informed, being appreciated); organisational career prospects ( evaluation of organisational career opportunities, departmental opportunities, internal labor markets, alternative opportunities); and job satisfaction. The questionnaire was divided into two parts, section A which elicited the respondents' biographical information, and section B, which elicited data on the annotated seven sub-scales. Questions in Section B were placed on a Likert type scale anchored by $1=V e r y$ satisfied to $5-=$ Very Dissatisfied. The Likert scale was utilised because as it is relatively easy to construct, makes data easy to collect and analyse, thereby making it suitable for surveys (Kothari, 2009).

\section{Statistical analyses}

The first step in this section was to establish the sample characteristics. The data analysis involved several statistical tests, namely descriptive inferential statistics and exploratory factor analysis (EFA), regression analysis and the meanscore ranking technique. These data analysis procedures were selected because of their applicability to the exploratory nature of the research design.

\subsection{Profile of Participants}

Demographic information on the respondents is provided in Table 1.

Table 1: Demographic profile of the respondents

\begin{tabular}{|c|c|c|c|c|}
\hline Variable & Categories & $\mathrm{N}$ & $\mathrm{N}$ & $\%$ \\
\hline \multirow{2}{*}{ Gender } & Males & 231 & 205 & 88.74 \\
& Females & 231 & 26 & 11.26 \\
\hline \multirow{3}{*}{ Employment period } & Less than 2yrs & 231 & 61 & 26.41 \\
& Between 2-5 years & 231 & 57 & 24.68 \\
& Between 6-9 years & 231 & 61 & 26.41 \\
& More than 9 years & 231 & 52 & 22.51 \\
\hline \multirow{2}{*}{ Type of employment } & Permanent & 231 & 52 & 22.51 \\
& Contract & 231 & 179 & 77.49 \\
\hline \multirow{3}{*}{ Trade Group } & Airframe & 231 & 69 & 29.87 \\
& Engines & 231 & 55 & 23.81 \\
& Avionics & 231 & 81 & 35.06 \\
& Sheet Metal Work & 231 & 26 & 11.26 \\
\hline \multirow{3}{*}{ Age group } & $18-25$ years & 231 & 32 & 13.85 \\
& $26-35$ years & 231 & 94 & 40.69 \\
& 36-45 years & 231 & 53 & 22.94 \\
& $46-55$ years & 231 & 41 & 17.75 \\
& 56+ & 231 & 11 & 4.76 \\
\hline
\end{tabular}


Table 1 indicates that $89 \%(n=205)$ out of the 231 participants were male and $11 \%(n=26)$ were female. Participants were drawn from the four aircraft engineering trade groups namely Airframe technicians $(30 \% ; n=69)$, engines technicians (24\%; $n=55)$, Avionics technicians $(35 \% ; n=81)$ and Sheet metal workers $(11 \% ; n=26)$. The majority of participants $(77.49 \% ; n=179)$ had been employed on ten year renewable contracts. The largest number of participants (40.69\%; n=94) were aged 26 and 35 years.

\subsection{Exploratory factor analysis (EFA)}

The factors contributing to the attrition of aircraft technicians were determined using exploratory factor analysis. Exploratory factor analysis is a statistical technique used to identify a set of latent (hidden) constructs underlying a battery of measured variables (Norris \& Lecavalier, 2009). It was selected for the current study because it is applicable when the researcher does not have an a priori hypothesis about the factors or patterns of measured variables (Malhotra, 2009), which is the case in the current study. To determine whether the data was suitable for a factor analysis, a Bartlett's test of Sphericity and the Keiser-Meyer-Olkin (KMO) measure of sampling adequacy were conducted, using the recommendation by Pett, Lackey and Sullican (2003). Both tests yielded values of: $p=0.001$ and 0.89 respectively, which indicated that it was feasible to conduct factor analysis on the captured data.

The data was subjected to principle component analysis (PCA) which allowed factors with eigenvalues greater than 1.0 to be extracted (Malhotra, 2010). As prescribed by Aldlaigan and Buttle (2002) item reduction and scale reduction were conducted in which communalities and low item-to-total correlations were subjected to successive examinations until an acceptable factor structure was attained (see table 2, above). Varimax rotation was applied in order to minimise the number of variables that had high loadings on any factor and to improve the degree to which the factors correlated and to make the interpretation easier (Malhotra \& Birks, 2003). The results are illustrated in Table 2.

Table 2: Rotated factor loadings, eigenvalues, variance, mean and reliability

\begin{tabular}{|c|c|c|c|}
\hline Factor Descriptors & Factor Loadings & Eigenevalue & Variance (\%) \\
\hline \multicolumn{2}{|l|}{ Factor 1: Job Satisfaction } & \multirow{10}{*}{5.662} & \multirow{10}{*}{18.264} \\
\hline The pride of being a member of this organisation & 0.600 & & \\
\hline The working conditions & 0.501 & & \\
\hline The level of professionalism in the organisation & 0.643 & & \\
\hline The opportunity for promotion & 0.768 & & \\
\hline Chance to do things that do not go against conscience & 0.820 & & \\
\hline The chance to be 'somebody' in the community & 0.843 & & \\
\hline The level of respect I get in the organisation & 0.649 & & \\
\hline Willingness to continue working for the organisation & 0.694 & & \\
\hline The enjoyment I get from my job & 0.562 & & \\
\hline \multicolumn{2}{|l|}{ Factor 2: Management style } & \multirow{7}{*}{4.082} & \multirow{7}{*}{13.167} \\
\hline The competence of supervisor in decision-making & 0.691 & & \\
\hline The way my boss handles his/her workers & 0.841 & & \\
\hline The style of leadership used by management & 0.624 & & \\
\hline The feedback I get from my boss & 0.674 & & \\
\hline The relationship between my boss and employees & 0.600 & & \\
\hline The respect I get from management & 0.625 & & \\
\hline \multicolumn{2}{|l|}{ Factor 3: Job Content } & \multirow{8}{*}{3.536} & \multirow{8}{*}{11.408} \\
\hline The number of hours I work & 0.403 & & \\
\hline The pressure I get from the amount of work I do & 0.614 & & \\
\hline The chance to work alone on the job & 0.535 & & \\
\hline The chance to try own methods of doing the job & 0.501 & & \\
\hline The freedom to use my own judgment & 0.585 & & \\
\hline The teamwork with my co-workers & 0.640 & & \\
\hline Adequacy of facilities and equipment for my job & 0.539 & & \\
\hline \multicolumn{2}{|l|}{ Factor 4: Economy and employment opportunities } & \multirow{5}{*}{1.962} & \multirow{5}{*}{10.329} \\
\hline The degree of national economy versus my needs & 0.656 & & \\
\hline The performance of my country's economy & 0.899 & & \\
\hline The availability of better employment opportunities & 0.882 & & \\
\hline Employment opportunities in other countries & 0.781 & & \\
\hline
\end{tabular}




\begin{tabular}{|l|l|l|l|}
\hline Factor 5: Employment equity & & \multirow{3}{*}{1.751} & \multirow{2}{*}{5.649} \\
\cline { 1 - 2 } My pay and the amount of work that I do & 0.768 & \\
My pay compared to other employees & 0.680 & & \\
Own salary to technicians in other organisations & & & \\
\cline { 1 - 2 } Factor 6: Individual cognition and personality & & & \\
\cline { 1 - 2 } The amount of time I spend with my family & 0.615 & & \\
The state of my mental and physical health & 0.656 & & \\
\hline
\end{tabular}

Table 2 indicates the rotated factor matrix, the eigen values and the percentage of variance explained of the six factors that were extracted. The factors are job satisfaction, management style, job content, economy and employment opportunities, employment equity and individual cognition and personality. The factors had a relatively high percentage of variance (64.88\%) which demonstrates their high contribution to the turnover of aircraft technicians.

\subsection{Scale Reliability and Mean Scores}

The internal consistencies (reliability), mean scores and position of each factor in the mean score rank are illustrated in Table 3.

Table 3: Internal consistencies and mean scores of factors

\begin{tabular}{|c|c|c|c|c|}
\hline Factor & $\begin{array}{c}\text { Number of } \\
\text { Items }\end{array}$ & $\begin{array}{c}\text { Reliability } \\
\text { (Cronbach alpha) }\end{array}$ & Mean Score & $\begin{array}{c}\text { Position In Mean } \\
\text { Score Rank }\end{array}$ \\
\hline Job satisfaction & 9 & 0.829 & 4.39 & 1 \\
\hline Management style & 6 & 0.794 & 3.91 & 5 \\
\hline Job content & 7 & 0.847 & 4.13 & 3 \\
\hline $\begin{array}{c}\text { Economy \& employment } \\
\text { opportunities }\end{array}$ & 4 & 0.721 & 4.16 & 2 \\
\hline Employment equity & 3 & 0.775 & 3.97 & 6 \\
\hline Individual cognition \& personality & 2 & 0.702 & 4.02 & 4 \\
\hline
\end{tabular}

An analysis of the internal consistency results (refer to Table 3) disclose that the reliabilities for all the extracted six factors as indicated by the Cronbach's alpha coefficients were acceptable. The minimum internal consistency of the factors was 0.702 and the maximum was 0.829 . These values were considered to be reliable because they were above the recommended threshold of 0.70 (Hair et al., 2010).

Analysis of the mean scores reveals that all the six factors had relatively high mean scores which ranged from 3.91 to 4.39 , which suggests that all factors were important to aircraft technicians. Among these, job satisfaction emerged as the most important factor while internal equity emerged as the least important factor to aircraft technicians.

\subsection{Multiple regression statistics}

Multiple regression analysis relates independent and dependent variables in a manner which takes mathematical intercorrelation into account (Malhotra, 2010). It is a statistical technique that can achieve the best linear prediction equation (Aldlaigan \& Buttle, 2002) between independent variables (in this case job satisfaction, economy and employment opportunities) and dependent variables (in this case job content, management style, employment equity and individual factors). Standard multiple regression analyses were performed to identify the variables that predicted or provided the best explanation for the portion of the total variance in the scores of the dependent variables. The results are presented in Table 4.

Therefore, the value of the adjusted $R^{2}$ was used to interpret the results. The $F$-test was used to test whether there was a significant regression between the independent and the dependent variables. For this study, $R^{2}$ values indicated large effect and treated as practically significant (Malhotra, 2010).

Table 4: Multiple regression analysis $(\mathrm{N}=231)$

\begin{tabular}{|c|c|c|c|c|c|c|c|}
\hline Variable & $\begin{array}{c}\text { Unstandardised } \\
\text { Coefficient }\end{array}$ & $\begin{array}{c}\text { Standardisedco } \\
\text { efficient }\end{array}$ & $t$ & $p$ & $F$ & $\begin{array}{c}\text { Adjusted } \\
R^{2}\end{array}$ & $R^{2}$ \\
\hline
\end{tabular}




\begin{tabular}{|c|c|c|c|c|c|c|c|c|}
\hline $\begin{array}{c}\text { Job Satisfaction } \\
\text { (constant) }\end{array}$ & $\begin{array}{c}b \\
2.06\end{array}$ & $\begin{array}{l}S E b \\
0.41\end{array}$ & $\beta$ & 5.03 & 0.043 & 26.78 & $\begin{array}{c}+++ \\
0.47^{\star \star \star}\end{array}$ & 0.76 \\
\hline Job content & 0.06 & 0.02 & 0.46 & 3.72 & 0.000 & & & \\
\hline Management style & 0.07 & 0.02 & 0.30 & 3.07 & 0.003 & & & \\
\hline Employment equity & 0.11 & 0.03 & 0.37 & 3.93 & 0.001 & & & \\
\hline $\begin{array}{l}\text { Economy, employment } \\
\text { opportunities }\end{array}$ & 0.12 & 0.02 & 0.44 & 5.17 & 0.000 & & & \\
\hline $\begin{array}{l}\text { Individual cognition \& personality } \\
\text { (constant) }\end{array}$ & $\begin{array}{c}b \\
-0.33\end{array}$ & $\begin{array}{l}S E b \\
0.59\end{array}$ & $\beta$ & -0.57 & 0.57 & 19.29 & $\begin{array}{c}+++ \\
0.26^{\star \star *}\end{array}$ & 0.53 \\
\hline Job content & 0.06 & 0.03 & 0.12 & 2.03 & 0.005 & & & \\
\hline Management style & 0.11 & 0.03 & 0.26 & 3.77 & 0.001 & & & \\
\hline Employment equity & 0.11 & 0.04 & 0.17 & 3.08 & 0.001 & & & \\
\hline $\begin{array}{l}\text { Economy, employment } \\
\text { opportunities }\end{array}$ & 0.07 & 0.03 & 0.43 & 2.55 & 0.001 & & & \\
\hline
\end{tabular}

*** $p \leq 0.001 ;{ }^{* *} p \leq 0.01 \quad{ }^{*} p \leq 0.05, d f---5,1407$,

$+R^{2} \leq 0.12$ (small practical effect) $++R^{2} \geq 0.13 \leq 0.25$ (medium effect) $+++R^{2} \geq 0.26$ (large practical effect)

Analysis results in Table 4 reveal that the job content $(\beta=0.46 ; p=0.000)$, management style $(\beta=0.30 ; p \leq 0.003)$, employment equity $(\beta=0.37 ; p=0.001)$, and economic and employment opportunities $(\beta=0.44 ; p \leq 0.000)$ positively predicted job satisfaction by explaining $47 \%$ of the variance. The measures of the Beta coefficients indicate that job satisfaction could be explained by the annotated components (the dependent variables). Economic benefits, availability of employment opportunities, employment equity, the pressure from supervisors and the pressure of daily workloads were the main barriers to greater job satisfaction.

The results of the regression analysis showed that style of management $(\beta=0.26 ; p=0.001)$ as well as economic and employment opportunities $(\beta=0.43 ; p=0.001)$ variables, contributed significantly to the variance in the individual cognition and personality (53\%), significantly predicting personal issues among aircraft technicians. Although they had impact on job satisfaction, it was interesting to note that job content $(\beta=0.12 ; p=0.005)$ and employment equity $(\beta=$ $0.17 ; p=0.0001$ ) were insignificant predictors of possible individual cognition and personality.

\section{Discussion of the results}

Staff turnover decisions have intrigued organisational theorists and human resource managers for a long time. Very often, job satisfaction, managerial style, career opportunities and economic returns reportedly mediate the behavioral distance between employee commitment and their quit behavior (Lytell \& Drasgow, 2009). The purpose of this study was to determine the factors influencing the attrition of aircraft technicians from the air force organisation. In this regard, the study identified six factors that contributed to the phenomenal exodus of these scarce skills.

\subsection{Explanation of the extracted factors}

Factor 1, which is labeled as job satisfaction, was concerned with the degree to which the needs of aircraft technicians were met by the organisation. This factor comprised of 9 items that were responsible for $18.26 \%$ of the total variance, indicating the importance of job satisfaction when dealing with military turnover. Respondents indicated that their level of satisfaction is low, which denotes that the organisation was failing to satisfy their needs. It is interesting to note that this result is in direct contrast to Hom et al.'s (1992) conclusion that the relationship between job satisfaction and the search for alternative employment was more pronounced in civilian than in military samples. A possible explanation for this phenomenon is provided by Boudreu, Boswell, Judge and Bretz (2001) who suggest that unmet needs and expectations may be a relatively vital factor in influencing military turnover.

Van de Ven (2003) found that the majority of young people who are employed on fixed-term contracts have a relatively instrumental attitude toward military work. The author adds that unmet expectations and disappointments concerning readily observable aspects of work have a great deal of influence in the decision to drop out. The very existence of basic motivation theories such as Herzberg et al. (1957) Hygiene Factors, McClelland's (1961) Three Needs Theory and Maslow's (1970) Hierarchy of Needs underscores the importance of meeting the needs of employees. Most respondents also indicated a high intention to leave the organisation. Thus, it is not surprising that studies have shown turnover intentions to be one of the best predictors of turnover (Steel \& Ovalle, 1984). This may imply that in order to 
arrest or prevent turnover within both military and civilian contexts, it is important to ensure that employee needs are met.

Labeled as management style and accounting for 13.17\% of the total variance, factor 2 was made up of 6 items. The present study found that respondents were unhappy with the manner in which their military leaders run the organisation. Important areas in regard to this matter include managements' competence in decision making, leadership style, nature of feedback provided to subordinates, policy implementation and the kind of relationship that exists between management and employees. The results of study imply that the style of leadership employed has the latent potential to either trigger or reduce military turnover. The results of the study are congruent to Eissenburg et al.'s (2002) assertion that sour relations between military leaders and subordinates are a major contributor to military turnover, while a healthy relationship between these two groups has the motivational effect of boosting a member's loyalty to the organisation.

Factor 3, identified as job content, was liable for $11.4 \%$ of the variance and was made up of 7 items. Previous research conducted by Van de Ven (2003) found job related factors to be a major reason behind employee turnover. Turnover is bound to be lower when the nature of work is such that an individual feels that their job is meaningful, highly engaging and enables the individual to develop a sense of pride in the job (Burchell, 2008). Participants of the current study indicated that they were unhappy with job related factors such as the working hours, workload, supervisors, availability of facilities and equipment, and teamwork, among others. Dunn and Morrow (2002) propose that frequent and long deployments, overnight duty, long working hours, high tempo, and work overload, typical of most military jobs are likely to play a critical role in shaping an individual's decision to join or to leave the military.

Factor 4, labeled as economy and employment opportunities; emphasised the link between labour turnover, economic conditions and the availability of employment opportunities elsewhere. This factor was accountable for $10.42 \%$ of the variance and consisted of 4 items. Results of the current study are diametrically opposite to Lytell and Drasgow's (2009) conclusion that perceived opportunities might not be an important part of military turnover processes. Respondents indicated that the availability of better employment opportunities both locally and internationally added a strong impetus in their desire to attrite. The behaviour of respondents is inconsistent with findings of Mobley et al. (1978) and Griffeth and Hom (2001) who concluded that the probability of finding a satisfactory alternative employment destination influences turnover intentions both directly and indirectly.

Prevailing economic and market conditions may cause employees to quit their jobs. Most respondents indicated their unhappiness with the economic conditions prevailing in their country during the period of the study. They noted that their country had been experiencing a severe economic depression characterised by hyperinflation and high unemployment rates. It is interesting to note that previous studies by Glaser (1996) found some indication that economic conditions may influence turnover. Another study conducted by (Johnny \& Magnus, 2003) found that correlations between job satisfaction and voluntary turnover were stronger when unemployment rate was lower, depicting a strong but negative correlation.

Alternative employment opportunities could indeed be available for the aircraft technicians. The mass recruitment of aircraft technicians by international aircraft maintenance companies such as GAMCO bears testimony to this fact. In support, Flightglobal (2008) suggests that there is a global shortage of aircraft technicians due to the fact that the baby boomers (those born in the 1950s) have now reached retirement age, thereby leaving a vacuum in the industry. By 2004, aircraft engineer numbers globally had halved despite the increase in numbers of operational aircraft in response to the boom that aviation was experiencing at that time (UK Government, 2004). The trend has since been exported into the second decade of the twenty first century (Flightglobal, 2012). Burchell (2008) also discloses that despite the surging record of aircraft orders in the aviation, the daunting challenge remains the shortage of qualified people to maintain all these aircraft. As such, the influence of the availability of alternative employment on labour turnover cannot be underestimated.

Factor $\mathbf{5}$ was labeled as employment equity and was concerned with the fairness of remuneration, eliminating any recruitment, selection, promotion or training practices that have the effect of being discriminatory and to providing a workplace where individuals are treated with respect (Coetzee et al., 2007). The factor was responsible for $5.65 \%$ of the variance and consisted of 3 items. Glaser (1996) found that the extent to which expected salary levels met achieved salary reduced the inclination to withdraw. The majority of respondents indicated that they were dissatisfied with their pay levels as well as what they were paid compared to the pay of other similar employees within and outside the organisation. The lack of internal and external equity can cause turnover in organisations (Dale-Olsen, 2006; Bockerman \& Ilmakunnas, 2009). Griffeth and Hom (2001) also add that individuals compare their job input-output ratios and the inputoutput ratios of others so as to eliminate any inequalities. Should any inequalities be perceived, people experience equity tension, feeling that they are overworked or under-rewarded. Quitting one's job may then be a way of attempting to correct the situation. 
Factor 6 was labeled as individual cognition and personality was related to one's private life and concerns. The factor consisted of two items and took up 5.1\% of the variance. Many of the respondents perceived that they were dissatisfied with conditions affecting their private lives. Individuals are attracted to, selected by, and stay with organisations that suit their personality characteristics (Cottini, Kato \& Westergaard-Nielsen, 2011). Other researchers (Schumm, Bell \& Resnick, 2001; Holden \& Scholtz, 2002; Dubihlela \& Dubihlela, 2011; Mafini, Surujlal \& Dhurup, 2011) emphasised the influence of family factors, health needs, emotional well being, person-environment fit, and other personalised needs on employee satisfaction and retention.

On the overall, the nature of work (job content), remuneration, workload and benefits are key drivers of satisfaction for the aircraft technicians. Satisfaction with the nature of work was found by Westlund and Hannon (2008) to be significantly related to an employee's intention to remain with an organisation. Jayawardena (2006) posits that employees value certain conditions of work. This implies that if the conditions of work are congruent with the individual cognition and personality needs, employees will be more satisfied and committed and less likely to leave the organisation. Tang et al. (2005) maintain that perceptions of fairness in compensation have a direct influence on organisational commitment and the compensation offers employees the opportunity for security, autonomy, recognition and improved self-worth, which consequently increases their sense worth, leading to commitment. It would also be important to understanding how these factors interfere with family life and what interruptions the technicians experience at home and at work.

\section{Concluding remarks}

The purpose of the study was to investigate the reasons behind the high attrition of aircraft technicians from an air force organisation in Southern Africa. It is worthy to note that on the overall, the current study generally produced interesting results. The most dominant view from the respondents is that the current operational climate in the organisation as well as their country were not conducive and has a snowball effect on the existing high rate of turnover. In practical terms, the new knowledge gained from observing the relationship between specific turnover factors for aircraft technicians may be useful in the attraction, selection, placement, development and-remuneration of talented employees in specialised technical environments.

The results suggest that in order to create a working environment that encourages people to stay with their respective organisations, managers need to review existing practices so as to offer fair working conditions, provide challenging and meaningful work tasks, and foster positive worker relationships. For an organisation's human resource management, results could be useful for talent retention, because it reveals comprehensive determining factors, helping managers analyse and diagnose the organisation's core employee movement.

There is a dearth of empirical studies and data on the turnover of aircraft technicians in the context of military organisations in Sub-Saharan Africa. Results of the study could therefore serve as a rich source of knowledge and an important contributor to the existing body of knowledge on labour turnover. Effective strategies to improve retention and reduce military turnover can only be developed when causes for leaving have been realistically identified.

\section{Limitations and implications for further research}

The limitations of data for a study conducted on a small sample within a small geographic location, as well as its aggregate nature, do not allow for a more elaborate empirical approach and demand caution when generalising the findings of this study. It is possible that the variables used are too general and fail to capture specific dimensions related to military turnover. While the study discussed different factors that may explain our results, the conclusions should remain tentative and that further empirical research may be needed to interrogate the various impediments highlighted in this study. Further empirical research on the same topic could be conducted on a sample made up of aircraft technicians who remain employed in the same organisations to examine whether similar results can be achieved or to establish if the same reasons could be sighted for the turnover. Such a study could have further implications on the reliability of the current study. Studies can also to be conducted on the turnover of specialist manpower in various military organisations, using larger samples than the one used in this study. This can provide fertile ground to examine the similarities and dissimilarities between the findings of such studies with those of the current study.

\section{References}

This article is not included in your organization's subscription. However, you may be able to under your organization's agreement with Elsevier. Aldlaigan, A. H., \& Buttle, F. A. (2002). SYSTRA-SQ: A new measure of bank service quality. Industrial Journal of Service industry Management, 
13(3), 362-381.

Asch, B., \& Hosek, J. (2007). The new economics of manpower in the post-cold war era. Handbook of Defence Economics, Vol. 2. Amsterdam.

Birchall, J., \& Morris, G. (1995). Business studies. Melbourne: Thomas Nelson.

Bockerman, P., \& Ilmakunnas, P. (2009). Job disamenities, job satisfaction, quit intentions, and actual separations: putting the pieces together. Industrial Relations, 48 (1), 73-96.

Bosman, J., Buitendach, J.H., \& Rothmann, S. (2005). Job insecurity, burnout and work engagement: The impact of positive and negative affectivity. South African Journal of Industrial Psychology, 31(4), 48-56.

Boudreu, J. W., Boswell, W. R., Judge, T. A., \&. Bretz, R. D. (2001). Personality and cognitive ability as predictors of job security among employed managers. Personnel Psychology, 24 (1), 25-50.

Bureau of Labor Statistics (2005). The employment situation: August 2005. News Release. United States Department of Labor.

Buddin, R. (2005). Success of first-term soldiers. Santa Monica, CA: Rand Corporation.

Burchell, B. (2008). The engineering challenge for MRO. Aviation Week 6. March. Retrieved March 3, 2012 from http://www.aviationweek.com/aw/generic/story_generic.jsp?channel=mro\&id=news/om308cvr.xml\&headline=The\%20Engineering\%20Cha llenge\%20For\%20MRO.

Campion, M. A. (1991). Meaning and measurement of turnover: Comparison of alternative measures and recommendations for research. Journal of Applied Psychology, 76 (2), 199-212.

Cigrang, J. A., Todd, S. L., \& Carbone, E. G. (2000). Stress management training for military trainees returned to duty after a mental health evaluation: Effect on graduation rates. Journal of Occupational Health Psychology, 5, 48-55.

Clark, R. P., \& Harcourt, M. (2004). The determination of employee behavior. Research and Practice on Human Resource Management, 8, $61-71$.

Coetzee, M., Schreuder, A.M.G., \& Tladinyane, R. (2007). Organisational commitment and its relation to career anchors. Southern African Business Review, 11(1), 65-86.

Copper, D. \& Schindler, P.(2011). Business research methods. $11^{\text {th }}$ ed.Boston. McGraw Hill.

Cottini, E., Kato, T., \& Westergaard-Nielsen, N. (2011). Adverse workplace conditions, high-involvement work practices and labor turnover: Evidence from Danish linked employer-employee data. Labour Economics, 18, 872-880.

Dale-Olsen, H. (2006). Wages, fringe benefits and worker turnover. Labour Economics 13 (1), 87-105.

Dickter, D. N., Roznowski, M., \& Harrison, D. A. (1996). Temporal tampering: An event history analysis of the process of voluntary turnover. Journal of Applied Psychology, 81, 705-716.

Döckel, A., Basson, J.S., \& Coetzee, M. (2006). The effect of retention factors on organisational Commitment, An investigation of high technology employees. South African Journal of Human Resource Management, 4(2), 20-28.

Dubihlela, J. \& Dubihlela, D. (2011). Youth attitudes towards advertisements depicting nudity and alcohol : ethical dilemmas in advertising. South African Journal of Psychology, 41(2), 207- 217.

Dunn, J., \& Morrow, R. (2002). Should I stay or should I go: Attrition questionnaire revision project - phase 1 findings. Sponsor Research Report No. 2002, 09 (Director Human Resources Research and Evaluation National Defence Headquarters, Ottawa, Ontario, K1A OK2).

Eissenburger, R., Stinglhamber, F., Vandenberghe, C., Surchaski, I., \& Rhodes, L. (2002). Percieved supervisor support to percieved organisational support contributions and employee retention. Journal of applied Psychology, 87, 3-6.

Ferreira, N. (2009). The relationship between psychological career resources and organisational commitment. Unpublished master's dissertation, Department of Human Resource Management, University of Pretoria, Pretoria.

Flightglobal. (2008). Aerospace faces a looming shortage of engineers. 14 April. Retrieved March 21,2012 from http://www.flightglobal.com/articles/2008/04/14/222942/aerospace-faces-a-looming-shortage-of-engineers.html.

Flightglobal. (2012). Global shortage of aircraft technicians persists. 6 September. Retrieved January 01,2013 from http://www.flightglobal.com/articles/2008/04/14/222942/aerospace-faces-a-looming-shortage-of-engineers.html.

Gerritse, B.M., Biert J, van Vugt, A.B., \& Scheffer, G.J. (2009). A single nighttime trauma helicopter does not represent a significant improvement in emergency assistance. Nederlands Tijdschrift voor Geneeskunde, 150 (30), 1701-2.

Glaser, D. N. (1996). The effects of quality of life factors on turnover and performance in the private sector. (Rep. No. NPRDC-TR-96-38). San Diego: Navy Personnel Research and Development Center.

Griffeth, W. R., \& Hom. P. W. (2001). Retaining valued employees. Thousand Oaks: Sage.

Hair, J. F., Black, B., Babin, B., Anderson, R. E., Tatham, R. L., \& Black, W. C. (2010). Multivariate data analysis: a global perspective. NY: Pearson Education Inc.

Herzberg, F., Mausner, B., Peterson, R. O., \& Capwell, D. F. (1957). Job attitudes: Review of research and opinion. Pittsburgh, PA: Psychological Service of Pittsburgh.

Holden, R. R., \& Scholtz, D. (2002). The Holden psychological screening inventory in the prediction of Canadian forces basic training outcome. Canadian Journal of Behavioural Science, 34 (2), 104-110.

Holden, N. (2010). Retention of Air Force Officers in the Canadian Forces: Paper presented at the $52^{\text {nd }}$ International Military Testing Association Conference, Lucerne, Switzerland, September 27 - October 1, 2010. Retrieved on March 32012 from http://www.imta.info/PastConferences/Presentations.aspx.

Hom, P. W., Caranikas-Walker, F., Prussia, G. E., \& Griffeth, R. W. (1992). A meta-analytical structural equations analysis of a model of employee turnover. Journal of Applied Psychology, 77, 890-909.

Hosek, J. R. \& Totten, M. (2002). Serving away from home: How deployments influence reenlistment. Santa Monica, Calif.: RAND MR-1594OSD. Retrieved January 13, 2012 from http://www.internationalmta.org/Documents/2004/204007P.pdf.

Jayawardena, N. (2006). A causal model of military turnover: a case study of the gunners in the Sri Lanka Air Force. Unpublished Masters Dissertation submitted to the University of Colombo, Sri Lanka.

Joāo, T.F. (2010). The relationship between perceived career mobility, career mobility preference, job satisfaction and organisational commitment. Unpublished master's dissertation. University of South Africa, Pretoria, South Africa.

Johnny, H. \& Magnus, S. (2003) Does job insecurity lead to impaired well-being or vice versa? Estimation of cross-lagged effects using latent 
variable modeling. Journal of Intellectual Capital, 5(2), 36 -41.

Knapp, D. J. (1993). Alternative Conceptualizations of Turnover. In J.P. Campbell (Chair), Prediction of turnover in a longitudinal sample using event history analysis. Symposium conducted at the $101^{\text {st }}$ annual convention of the American Psychological Association, Toronto, Canada, August.

Kothari, C. R. (2009). Research methodology: Methods and techniques. $2^{\text {nd }}$ ed. New Delhi: New Age International.

Krueger, G. P. (2001). Military psychology: United States. International Encyclopedia of the Social \& Behavioral Sciences. Retrieved January 12 , 2012 from http://www.internationalmta.org/Documents/2004/204017P.pdf. Accessed: 2012.01. 12.

Lane, M. E. (2006). Predictors of attrition from the U.S Navy delayed entry program. Unpublished PhD dissertation, University of Memphis, Memphis.

Lytell, M. C., \& Drasgow, F. (2009). Timely methods: Examining turnover rates in the U.S. Military. Military Psychology, 21:334-350.

Mafini, C., Surujlal, J., \& Dhurup, M. (2011). Factors affecting the job satisfaction of municipal sports officers. African Journal for Physical, Health Education, Recreation \& Dance. September (Supplement 1), 145-156.

Malhotra. N. K., \& Birks, D. F. (2003). Marketing research: An applied approach. (2nd ed). London: Prentice-Hall.

Malhotra, N. K. (2007). Marketing research: An applied orientation. $2^{\text {nd }}$ ed. New Jersey, Upper Saddle River: Prentice-Hall.

Malhotra, N. K. (2009). Marketing research: an applied orientation. 6rd ed. Eaglewood Cliffs, NJ: Prentice- Hall.

Malhotra, N . K. (2010). Marketing research: An applied orientation. (6 $6^{\text {th }}$ ed) New Jersey: Prentice-Hall.

Marcourse, I, Gillespie A, Martin, B, Surredge, M., \& Wall, N. (2002). Business Studies. London: Hodder and Stroughton.

Maslow, A.H (1970), Motivation and personality. New York, NY: Harper \& Row.

McClelland, D.C (1961), The achieving society. New York, NY: Van Nostrand Reinhold.

Meyer, J., \& Allen, N. (1997). Commitment in the workplace: Theory, research and application. London: Sage.

Morrow, P.C. (2011). Managing organizational commitment: Insights from longitudinal research. Journal of Vocational Behavior, 79, 18-35.

Mouritsen, J., Bukh, P. N. \& Marr, B. (2004). Reporting on intellectual capital: why, what and how? Measuring Business Excellence, 8(1), $46-54$.

Murnieks, C. Y. Scot T. Allen, S. T., \& Claudia J. Ferrante, C. J. (2011). Combating the effects of turnover: Military

lessons learned from project teams rebuilding Iraq. Business Horizons, 54 (5), 481-491.

Norris, M. \& Lecavalier, L. (2009). Evaluating the use of exploratory factor analysis in Developmental Disability Psychological Research. Journal of Autism and Developmental Disorders, 40 (1): 8-20.

Pett, M. A., Lackey, N. R. \& Sullivan, J. J. (2003). Making sense of factor analysis: the use of factor analysis for instrument development in health care research. Thousand Oaks: Sage.

Saari, L., \& Judge, T. 2004. Employee attitudes and job satisfaction. Human Resource Management, 43(4), 395-407.

Schaufeli, W. B., \& van Dierendonck, D. (1993). The construct validity of two burnout measures. Journal of Organisational Behavior, 14, $631-647$.

Schumm, W. R, Bell, B. D., \& Resnick, G. (2001). Recent research on family factors and readiness: Implications for military leaders. Psychological Reports, 89, 153-166.

Schwerdt, G., Ichino, A., Ruf, O., Winter-Ebmer, R., \& Zweimüller, J. (2010). Does the color of the collar matter? Employment and earnings after plant closure. Economics Letters 108 (2), 137-140.

Smith, D. R., Holtom, B. C., \& Mitchell, T. R. (2011). Enhancing precision in the prediction of voluntary turnover and retirement. Journal of Vocational Behavior, 79 (1), 290-302.

Spector, P. 1997. Job satisfaction: Application, assessment, causes and consequences. California: Sage.

Steel, R. P., \& Ovalle, N. K. (1984). A review and meta-analysis of research on the relationship between behavioral intentions and employee turnover. Journal of Applied Psychology, 69, 673-686.

Stroth, C. (2010). Job embeddedness as a nurse retention strategy for rural hospitals. Journal of Nursing Administration, 40(1), 32-35.

Sumer, H, C. (2005). A Causal model of military turnover. Unpublished manuscript, Middle East Technical University, Ankara, Turkey. Retrieved May 22, 2012 from http://www.internationalmta.org/Documents/2004/2004018P.pdf. Accessed 2012: 05.22.

Talcott, G. W., Haddock, K., Klesges, R. C., Lando, H., \& Fiedler, E. (1999). Prevalence and predictors of discharge in United States Air Force basic military training. Military Medicine, 164, 269-274.

Tang, T. L., Kim, J. K., \& Tang D. (2005). Does attitude towards money moderate the relationship between intrinsic job satisfaction and voluntary turnover? Human relations, 5, 213-241.

UK Government. (2004). Aircraft maintenance engineers and training: Will safety be affected. Report on the Training of

Aircraft Maintenance Engineers. Retrieved June 62012 from http://www.airengineers.org/docs/news/aircraft_maintenance engineer_shortage.pdf.

Van de Ven, C. P. H. W. (2003). The drop-out rate during training: In line with expectations? Research Report. Behavioral Sciences Division, The Royal Netherlands Army.

Van Dyk, J., \& Coetzee, M. (2012). Retention factors in relation to organisational commitment in medical and information technology services. SA Journal of Human Resource Management, 10(2), 433-444.

Van Schalkwyk, S., Du Toit, D.H., Bothma, A.S., \& Rothmann, S. (2010). Job insecurity, leadership empowerment behaviour, employee engagement and intention to leave in a petrochemical laboratory. SA Journal of Human Resource Management, 8(1), 234-243.

Von Greiff, J. (2009). Displacement and self-employment entry. Labour Economics 16 (5), 556 -565.

Warner, J. \& Asch, B. (2001). The record and prospects of the all-volunteer military in the U.S. Journal of Economic Perspectives, 15(2), 169192.

Westlund, S.G., Hannon, J.C. (2008). Retaining talent: assessing job satisfaction facets most significantly related to software developer turnover intentions. Journal of Information Technology Management, 19 (4), 1-15. 